\title{
Marco Migliore, Cinzia Talamo e Giancarlo Paganin Strategies for Circular Economy and Cross-sectoral Exchanges for Sustainable Building Products. Preventing and Recycling Waste
}

Springer Nature, 2019

Negli ultimi vent'anni l'interrelazione tra gestione dei rifiuti, produzione di emissioni e relativi impatti diretti o indiretti è stata ampiamente analizzata (IPCC) e la sua rilevanza è stata evidenziata in particolare con riferimento al settore delle costruzioni, i cui flussi produttivi continuano a costituire uno dei più significativi contributi in questo ambito. Si stima che circa un terzo dell'intera produzione di rifiuti nell'Unione Europea provenga dal settore delle costruzioni, considerando sia i processi di realizzazione che quelli di demolizione. Adottando una prospettiva più ampia, molti altri impatti legati ai rifiuti vengono generati all'interno delle città e la gestione dei rifiuti è tuttora considerata una priorità per la maggior parte dei soggetti politici e delle pubbliche amministrazioni. Guardando all'ambiente urbano, si prevede infatti un ulteriore aumento dell'attuale trend di produzione di rifiuti sia per effetto della crescita della popolazione che per la correlata evoluzione dei consumi e degli stili di vita. Nonostante gli sforzi spesi nella definizione e nell'adozione di diverse misure, direttive e regolamenti per supportare le città nella riduzione della quantità di rifiuti generata, il tasso di materiali riciclati è ancora al di sotto delle soglie previste in molti paesi mentre l'impiego di discariche e inceneritori continuano a rimanere le soluzioni prevalentemente utilizzate raggiungendo livelli sempre più allarmanti.

In the last twenty years the interrelation of waste management, emissions production and related direct or indirect impacts has been largely reported (IPCC) and its relevance has been particularly evidenced with reference to the building sector, whose production streams still represent a major contributor within this topic. It is estimated that approximately one-third of whole waste production across EU comes from the building sector considering both the construction process and the demolition phase. If a broader perspective is adopted many other waste-related impacts are generated within cities and waste management is still considered a priority for most of policy makers. Looking at the urban environment, the current trend in waste production is indeed expected to further increase due to both the population growth and the related evolution of consumes and lifestyles.

Despite the effort spent in defining and adopting several measures, directives and regulations to support cities in reducing the generated amount of waste, the rate of recycled materials is still under the targeted thresholds in many countries while the adoption of landfilling or burning practices are reaching alarming levels.

The ambition of Agenda 2030 to strongly reduce emissions and impacts clearly emerges in the UN Sustainable Development Goal 12.5 targeting to «substantially reduce waste generation through prevention, reduction, recycling and reuse» that basically means to primarily rethink the current economic models and production strategies. A first and relevant shift in the mindset deals with assuming waste as a potential resource to be further

Lambizione dell'Agenda 2030 di ridurre fortemente le emissioni e gli impatti è ben sintetizzato dal Sustainable Development Goal 12.5 delle Nazioni Unite che mira «a ridurre sostanzialmente la produzione di rifiuti attraverso la prevenzione, la riduzione, il riciclaggio e il riutilizzo» che sostanzialmente significa ripensare primariamente gli attuali modelli economici e le strategie di produzione. Un primo e rilevante cambiamento di mentalità riguarda l'assunzione dei rifiuti come potenziale risorsa da reintrodurre nei processi produttivi secondo nuovi modelli che non si basino più sull'utilizzo di materie prime, la cui estrazione vede una crescita prevista pari a oltre il doppio entro il 2050, seguendo uno scenario business-as-usual. Ladozione di modelli circolari in luogo di quelli lineari rappresenta certamente un passo avanti fondamentale per affrontare la sfida di ripensare completamente sia la produzione che la consegna dei prodotti. Il libro di Marco Migliore, Cinzia Talamo e Giancarlo Paganin propone unarticolata riflessione sugli elementi chiave e sugli attuali ostacoli a questa trasformazione offrendo alcuni spunti sul ruolo che la progettazione strategica riveste nei processi produttivi, sull'importanza di creare condizioni adeguate per rendere il processo di riciclo attuabile ed efficace all'interno di una produzione più sostenibile, sull'importanza di considerare l'adozione di nuovi modelli nel settore delle costruzioni tenendo conto della prospettiva sull'intero ciclo di vita, sul ruolo della tecnologia nell'abilitare sia i produttori che i consumatori ad assumere una parte attiva all'interno del progetto di trasformazione, sull'importanza dell'informazione e della comunicazione nell'affrontare il cambiamento di modello cogliendo le esigenze e le priorità emergenti, sfruttando al contempo il loro potenziale di mercato.

exploited in the production processes according to new models which are no longer based on the use of raw materials whose extraction is estimated to grow of more than a double until 2050 following the business-as-usual scenario. The adoption of circular models instead of the linear take-make-disposal one is certainly a crucial step forward in facing the challenge to completely re-think both production and delivery of products. The book edited by Marco Migliore, Cinzia Talamo and Giancarlo Paganin offers an articulated reflection on the key elements and the current barriers concerning this shift offering some insights about the role of strategic design in manufacturing processes, the importance of creating proper conditions to make the recycling process viable and effective within a more sustainable production, the relevance of considering the adoption of new models in the building sector taking into account the whole life cycle perspective, the role of technology in habilitating both producers and consumers in taking an active part within the drafted change, the importance of information and communication in addressing the model shift capturing emerging needs and priorities while exploiting their market potential.

As the book suggests, this requires establishing a truly open and crosssectorial cooperation that goes beyond the traditional disciplinary boundaries to support the prevention of avoidable waste generation and to recognize the waste market potential, stimulating new market-oriented perspective and new entrepreneurial opportunities that would particularly benefit of the forthcoming Green Deal and Recovery Plans. However, the associated complexity and the plurality of subjects 
Come suggerisce il libro, ciò richiede la creazione di una cooperazione veramente aperta e intersettoriale che vada oltre $i$ tradizionali confini disciplinari per supportare la prevenzione della produzione di rifiuti e per riconoscere l'eventuale potenziale di mercato, stimolando nuove prospettive e nuove opportunità imprenditoriali che potrebbero vantaggiosamente intercettare gli obiettivi del Green Deal e del Recovery Plan. Tuttavia, la complessità del sistema e la pluralità di soggetti potenzialmente coinvolti, provenienti da settori diversi, costituiscono non trascurabili ostacoli a una rapida ed efficace adozione e implementazione di modelli circolari, in particolare su scala più ampia dove le sinergie richiederebbero certamente maggiori sforzi nel coordinamento dei processi e delle iniziative ma garantirebbero anche un maggiore sfruttamento dei risultati. Il settore delle costruzioni ha sperimentato con successo l'uso di materie prime seconde nello sviluppo di componenti edilizi alternativi o sostituendo alcuni elementi di base di diversi prodotti da costruzione dimostrando la fattibilità tecnica ed economica di modelli a base circolare.

Nonostante questi risultati promettenti, l'impegno e la disponibilità dei produttori di materiali da costruzione nell'adozione di modelli innovativi sono ancora limitati, non tanto per ragioni tecniche ma soprattutto per la capacità di comprenderne il potenziale di mercato. La mancanza di una efficace rete di collegamento tra i produttori che possono offrire rifiuti riciclabili e coloro che ne esprimono una domanda rappresenta attualmente una delle principali lacune nella creazione di una efficace catena di processo. Allo stesso tempo, la capacità del progetto di guidare il mercato in questa direzione appare ancora limitata. Un importante contributo può quindi venire dalle normative nazionali o

potentially involved from different sectors still represents an obstacle to a rapid and effective adoption and implementation of circular model, particularly at a broader scale where synergies would certainly require greater efforts in coordinating processes and initiatives but also ensuring larger room for results exploitation. The building sector successfully experimented the use of secondary raw materials to develop alternative building components or to replace the basic elements of some building products demonstrating the technical and economic viability of circular based models.

Despite these promising results, the commitment and availability of building materials producers in adopting innovative models is still limited, not really because of technical capacity but mainly of market potential understanding. The lack of connections internazionali che riguardano la certificazione dei prodotti da costruzione, in particolare quelle relative alla valutazione degli impatti ambientali.

Rilevando queste lacune e opportunità, gli autori offrono una panoramica articolata del tema spaziando dalle cause che limitano un più rapido sviluppo e adozione di modelli circolari all'esame di possibili soluzioni che permettano di superare i confini di settore stimolando approcci collaborativi e promettenti nell'ambito delle diverse fasi di produzione. Ciascuno dei nove capitoli contribuisce a restituire un quadro del tema che spazia dal contesto generale del quadro politico di riferimento dell'Unione Europea ad applicazioni concrete, evidenziando anche alcuni nuovi aspetti interessanti riguardanti l'uso di sistemi ICT, sia per comunicare informazioni o dati sia per gestire il processo, così come il coinvolgimento della più ampia comunità di cittadini nell'assumere un ruolo attivo nel cambiamento.

Il libro offre la possibilità di riflettere sulla mancanza di una visione sistemica in grado di guidare con coerenza il passaggio dai modelli convenzionali a quelli circolari evidenziando ancora una volta la necessità che le azioni di progettazione strategica siano promosse e supportate ai diversi livelli dal convergente interesse degli stakeholder e dei soggetti politici coinvolti.

Jacopo Gaspari between producers who can offer recyclable waste and those who are expressing a demand of them is currently one of the main gaps in establishing an effective process loop. At the same time, the capacity of strategic design to drive the market in this direction appears still limited, thus a major contribution may come from national or international regulations dealing with building products certificates particularly those regarding the assessment of products environmental impacts.

Detecting these gaps and opportunities the authors offer an articulated overview of topic drafting the causes limiting a faster development and adoption of circular models while exploring possible pathways to overcome sectorial boundaries and to stimulate cooperative and promising approaches within the production streams at the different stages. Each of the nine chapters contributes in drafting a picture of the topic that ranges from the overall general context of EU policy framework to concrete applications, also pointing out some new interesting aspects concerning the use of ICT, both to communicate information or data and to manage the process as well as the involvement of the broader community of citizens in becoming a proactive part of the change.

The book offers the chance to reflect on the lack of a systemic vision able to coherently drive the shift from conventional models to circular ones highlighting once again the need for strategic design actions to be promoted and supported at different levels by the converging interest of stakeholders and policy makers.

Jacopo Gaspari 